Summer 2011

\title{
Money Can't Buy You Law: The Effects of Foreign Aid on the Rule of Law in Developing Countries
}

Katherine Erbeznik

Indiana University Maurer School of Law

Follow this and additional works at: https://www.repository.law.indiana.edu/ijgls

Part of the Banking and Finance Law Commons, and the Rule of Law Commons

\section{Recommended Citation}

Erbeznik, Katherine (2011) "Money Can't Buy You Law: The Effects of Foreign Aid on the Rule of Law in Developing Countries," Indiana Journal of Global Legal Studies: Vol. 18 : Iss. 2 , Article 9.

Available at: https://www.repository.law.indiana.edu/ijgls/vol18/iss2/9

This Note is brought to you for free and open access by the Law School Journals at Digital Repository @ Maurer Law. It has been accepted for inclusion in Indiana Journal of Global Legal Studies by an authorized editor of Digital Repository @ Maurer Law. For more information, please contactrvaughan@indiana.edu.

\section{$\Psi$}

JEROME HALL LAW LIBRARY

INDIANA UNIVERSITY

Maurer School of Law
Blooming ton 


\title{
Money Can't Buy You Law: The Effects of Foreign Aid on the Rule of Law in Developing Countries
}

\author{
KATHERINE ERBEZNIK*
}

\begin{abstract}
The rule of law is often touted as a panacea for the problems faced by the developing world. As a result, billions of dollars in foreign aid have been spent trying to promote the rule of law in developing countries. However, in many cases, little observable progress has been made. This Note explores some of the reasons rule of law reform efforts have stalled. One reason is that reform has focused solely on formal rule of law institutions, rather than on the informal political or cultural norms that are needed to support such institutions. Little is known, however, about how to foster such political and cultural norms where they are lacking. This Note argues that, at a minimum, fostering such norms requires a will to reform on the part of governments and political elites. Foreign aid, in the form of monetary transfers, has negative unintended consequences on the will to reform. By drawing on the economic literature detailing how foreign aid can provide perverse incentives for developing country governments, this Note argues that foreign aid decreases the incentives of governments and political elites to adopt a will to reform. In turn, this makes rule of law reform less likely to be successful.
\end{abstract}

\footnotetext{
* Executive Notes Editor, Indiana Journal of Global Legal Studies; J.D. Candidate, 2011, Indiana University Maurer School of Law; Ph.D. Philosophy, 2008, Bowling Green State University; B.A., 2001, University of California-Berkeley. I would like to thank Feisal Amin Rasoul Istrabadi, Christiana Ochoa, Fernando Tesón, and Nicolás Maloberti for their helpful comments on earlier drafts of this Note.
}

Indiana Journal of Global Legal Studies Vol. 18 \#2 (Summer 2011) (c) Indiana University Maurer School of Law 


\section{INTRODUCTION}

The rule of law is often touted as a panacea for problems facing the developing world. ${ }^{1}$ It is thought to obviate violent conflicts and allay postconflict turmoil. ${ }^{2}$ It also is attributed with the power to accelerate economic development and protect human rights. ${ }^{3}$ With all of the wonders the rule of law is credited with providing, it may be a surprise to learn that despite decades of reform efforts, very few of these wonders have been realized. ${ }^{4}$ Blame for the disappointing result of international efforts to build the rule of law in developing countries may not lie with the rule of law itself; it might just be the panacea everyone hopes. The problem is that despite decades of experience, there is still no blueprint for how to build the rule of law where it is lacking. ${ }^{5}$ Efforts to build the rule of law without such a blueprint have often been disastrous for the presumed beneficiaries.

This Note does not attempt the herculean task of drawing the needed blueprint, supposing one could even be drawn. Instead, this Note addresses a further potential roadblock to rule of law reform: foreign aid. ${ }^{6}$ While the target of monetary transfers of foreign aid is often economic development or poverty reduction and only indirectly the improvement or development of the rule of law, ${ }^{7}$ targeting economic development through foreign aid often has deleterious consequences on the rule of law. There is a growing economic literature that highlights the negative consequences foreign aid can have on economic

1. E.g., Thomas Carothers, The Rule-of-Law Revival, in PROMOTING THE RULE OF LAW ABROAD: IN SEARCH OF KNOWLEDGE 3 (Thomas Carothers ed., 2006) [collection hereinafter PROMOTING THE RULE OF LAW ABROAD].

2. See, e.g., Chandra Lekha Sriram, Prevention and the Rule of Law: Rhetoric and Reality, in CIVIL WAR AND THE RULE OF LAW: SECURITY, DEVELOPMENT, HUMAN RIGHTS 71 (Agnès Hurwitz \& Reyko Huang eds., 2008) [collection hereinafter CIVIL WAR AND THE RULE OF LAW] (examining the rule of law as a tool for conflict prevention); see also William G. O'Neill, UN Peacekeeping Operations and Rule of Law Programs, in supra, at 91 (arguing that "the rule of law is an essential prerequisite for building a modicum of trust in war-torn societies").

3. For the relationship between the rule of law and economic development, see generally KenNETH W. DAM, THE LAW-GrowTh NEXUS: The RULE OF LAW AND ECONOMIC DEVELOPMENT (2006).

4. See, e.g., Stephen Golub, A House Without a Foundation, in Promoting THE RULE OF LAW ABROAD, supra note 1 , at 105, 112-15.

5. See Thomas Carothers, The Problem of Knowledge, in PRomoting THE RULE of LAW ABROAD, supra note 1, at 15.

6. Foreign aid can be used to describe various sorts of international assistance, from technocratic expertise to monetary transfers. For the purpose of this Note, foreign aid is used to describe monetary transfers. The main point is that such monetary transfers undermine technocratic assistance and rule of law reform.

7. See Golub, supra note 4, at $107,109$. 
development. This Note draws on that literature to explore the ways in which foreign aid may negatively impact rule of law reform efforts. It concludes that not only can money not buy the rule of law, but it can hinder rule of law reform as well.

Part I of this Note briefly explores the concept of the rule of law and previous efforts to build it in developing countries. This part highlights that previous reform efforts have often failed because reformers largely ignore the cultural or political elements of the rule of law and the difficulty inherent in fostering such elements. Part II surveys the economic literature surrounding the effects of foreign aid on economic development and finds that much of this literature applies equally to rule of law reform. This part suggests that attempts to build the rule of law may be frustrated by influxes of foreign aid, much in the same way economic development has been frustrated. Lastly, part III highlights the findings in part II by looking at the effects of foreign aid on the countries of sub-Saharan Africa. While it is certainly not possible to conclude that foreign aid is the only reason why the rule of law is weak in much of sub-Saharan Africa, this Note sheds some light on the ways in which foreign aid could be a roadblock to rule of law reform.

\section{THE RULE OF LAW}

The rule of law is seen as a fundamental element of developed countries; an element that developing countries must foster in order to escape the trenches of poverty. This part explores what the rule of law means and why efforts to foster it in developing countries have been unsuccessful.

\section{A. Defining the Rule of Law}

The rule of law is an expansive concept, subject to multiple meanings. ${ }^{8}$ It can refer to a set of rules that binds governments and individuals, ${ }^{9}$ the presence and quality of specific legal or political institutions, ${ }^{10}$ or the adequate protection of equality or human rights. ${ }^{11}$

8. See generally Rachel Kleinfeld, Competing Definitions of the Rule of Law, in PROMOTING THE RULE OF LAW ABROAD, supra note 1, at 31. For a taxonomy of various rule of law concepts, see Richard H. Fallon, Jr., "The Rule of Law" as a Concept in Constitutional Discourse, 97 Colum. L. REv. 1 (1997); William C. Whitford, The Rule of Law, 2000 WIS. L. REV. 723.

9. See Kleinfeld, supra note 8, at $36-44$.

10. See id. at 47-48. 
Formal theories define the concept as a system of rules that are transparent, public, and enforced regularly, predictably, and equally against all persons, both citizens and political elites. ${ }^{12}$ In particular, government accountability to the rule of law is held as the sine qua non of the rule of law, ${ }^{13}$ and it comprises a core tenet of formal theories of the rule of law. The institutional approach defines the rule of law as a set of specific formal institutions, such as written legal codes, independent judiciaries, effective law enforcement bodies, ${ }^{14}$ and democratic government. ${ }^{15}$ According to the substantive approach, the rule of law requires the realization of certain normative values, such as substantive equality or the protection of human rights. ${ }^{16}$ These concepts are not mutually exclusive; in fact, substantive theories encompass certain formal rule of law elements, ${ }^{17}$ and both substantive and formal theories include institutional elements.

In theory, it does not matter whether the rule of law has one meaning or many. The trouble lies in evaluating the efficacy of rule of law reform efforts without defining what would count as successful reform, ${ }^{18}$ for the "know it when you see it" approach is untenable. ${ }^{19}$ Furthermore, promoting one conception of the rule of law may often conflict with the promotion of another. ${ }^{20} \mathrm{It}$ is, therefore, important to postulate what meaning of the rule of law is being used here to evaluate whether foreign aid undermines that concept.

11. See id. at 44-46. See generally BRIAN Z. TAMANAHA, ON THE RULE OF LAW: HISTORY, POLITICS, THEORY 91-113 (2004) (providing an in-depth look at formal and substantive theories of the rule of law, and the differences between the two).

12. Kleinfeld cites Friedrich Hayek as a principal proponent of predictability as a byproduct of the rule of law. Kleinfeld, supra note 8, at 42-44 (referring to Hayek's work in The RoAD TO SERFDom (1994)). Fallon cites both Hayek and John Rawls as holding this "formalist" view of the rule of law. Fallon, supra note 8, at 16.

13. Kleinfeld, supra note 8 , at 37 .

14. Id. at 47-48.

15. See TAMANAHA, supra note 11 , at $91,99-101$. Tamanaha sees democracy as an extension of the "formal" rule of law concept. Democratic accountability and rule making may be part of a "thicker" formal rule of concept-that is, with more requirements, but democracy itself is best understood as an institution.

16. See Kleinfeld, supra note 8, at 44-46.

17. JANE STROMSETH ET AL., CAN MIGHT MAKE RighTS? 70-71 (2006).

18. See Thom Ringer, Note, Development, Reform, and the Rule of Law: Some Prescriptions for a Common Understanding of the "Rule of Law" and Its Place in Development Theory and Practice, 10 YALE HUM. RTS. \& DEV. L.J. 178, 182 (2007) (explaining that if rule of law reforms are to be effective, they "must establish clear institutional benchmarks," yet "conceptual anarchy about the meaning of the rule of law is likely to produce competing and conflicting benchmarks in different states and systems").

19. STROMSETH ET AL., supra note 17, at 56-58.

20. E.g., Kleinfeld, supra note 8, at 59-61. 
This Note focuses on the formal rule of law theory, ${ }^{21}$ because, at a minimum, the rule of law encompasses the idea of a well-ordered society; one in which there is a "government of laws, and not of men."22 The formal rule of law is as much a political and cultural concept as it is a legal one. ${ }^{23}$ In this sense, the rule of law is both a set of formal rules, which are public and transparent, and to which both the government and its citizens are held accountable, and a set of social norms, which reflect a cultural commitment to submit to the formal law as a means of dispute resolution or democratic decision-making process. ${ }^{24}$ Indeed, it is the failure to recognize this cultural and political content in the formal rule of law that has undermined efforts to build the rule of law in developing countries. ${ }^{25}$

\section{B. Building the Rule of Law in Developing Countries}

The last century saw the emergence of new nations, as many countries in Africa and Asia broke free of their colonial masters. ${ }^{26}$ It also saw the collapse of the Soviet Union, ${ }^{27}$ after which countries comprising the Eastern Bloc regained their independence. These transformations provided a unique opportunity for countries to unshackle themselves from historical traditions and build new economic and political institutions. ${ }^{28}$ Inspired by this opportunity, a development industry has emerged, drawing economists, political scientists, lawyers, and technocrats into its fold. Development efforts have focused on economic, legal, and political institutions, including democratic transition to

21. For a more detailed description of a formal rule of law concept, see Robert $\mathrm{S}$. Summers, A Formal Theory of the Rule of Law, 6 RATIO JURIS 127 (1993).

22. MASS. CONST. art. XXX (drafted by John Adams). The rule of law concept has a long pedigree, tracing its roots to Plato and, more recently, Adams. See DAM, supra note 3, at 13. By adopting this concept of the rule of law, it does not follow that expressio unius est exclusio alteruis. That is to say, by adopting the formal rule of law concept, I am not making an evaluative judgment about the superiority of formal concepts over substantive ones. The formal rule of law is a necessary, though perhaps not sufficient, condition for having a rule of law society.

23. Kleinfeld, supra note 8 , at 51; see also Rosa Ehrenreich Brooks, The New Imperialism: Violence, Norms, and the "Rule of Law," $101 \mathrm{MICH}$. L. REV. 2275, 2285-86 (2003).

24. Brooks, supra note 23, at n.50. Friedrich Hayek is thought to espouse the rule of law theory adopted here by Brooks. See Tamanaha, supra note 11, at 58 (citing FrIEDRICH A. HAYEK, The CONSTITUTION OF LIBERTY 206 (1960)).

25. Brooks, supra note 23 , at 2289.

26. Carothers, supra note 5 , at 16 .

27. Brooks, supra note 23, at 2278.

28. See, e.g., Francis FukUyama, State-BuIlding: Governance and World Order IN THE 21ST CENTURY 2 (2004). 
economic development to rule of law reform. Yet, despite the plethora of experts and outpouring of development aid, results have often been disappointing. ${ }^{29}$ One explanation of why this is the case is offered in the following sections.

The next two sections discuss rule of law reform efforts and the challenges that those efforts face. These sections conclude that rule of law reform will continue to produce lukewarm results unless political elites adopt the will to enact reforms. In other words, there must be sincere demand for rule of law reform before the development industry can assist in the supply, and currently, that demand is lacking. ${ }^{30}$

\section{Rule of Law Reform}

The problem with past rule of law reform efforts is that reformers tried to promote the formal rule of law by focusing solely on its institutions, such as legal codes, judiciaries, and police forces. This furthers the myth that technocratic expertise must rewrite legal codes to mirror the legal codes of Western societies, ${ }^{31}$ train judiciaries to think and act like Western judiciaries, and modernize legal institutions to make them as efficient as legal institutions in Western societies. ${ }^{32}$ Rule of law reform efforts that embody this myth assume a "build it and they will come" 33 approach, meaning if the "right" formal institutions are in place, the rule of law will simply emerge. However, good laws are meaningless if they are not followed or enforced, training the judiciary or police force is pointless if the incentives for corruption are not mitigated, and efficient legal institutions are just for show if no one trusts or uses them. ${ }^{34}$ While the rule of law does encompass the idea of transparent and public laws, equal and predictable enforcement, and accountability, it is more than a set of formal institutions. The fallacy of this approach is that it ignores the political or cultural element of the rule of law..$^{35}$

29. Brooks, supra note 23 , at 2280 .

30. Fukuyama, for example, expresses reservations about external actors' ability to create demand for institutions. FUKUYAMA, supra note 28 , at $32-42$. Carothers also recognizes that one of the primary obstacles to rule of law reform is a lack of the will to reform. Carothers, supra note 1 , at 4 .

31. While there is room for debate as to whether Western societies, like the United States or Great Britain, exhibit the rule of law as it is defined in this Note, they are generally thought to be the closest to the norm.

32. See generally Kleinfeld, supra note 8 , at 47-54 (discussing the conventional thinking of practicioners engaged in institution modeling).

33. Golub, supra note 4, at 106; see also STROMSETH ET AL., supra note 17, at 73.

34. STROMSETH ET AL., supra note 17 , at 76, 178-80.

35. See id. at 75-77; Brooks, supra note 23 , at 2284-86. 
The cultural or political element of the rule of law is the relationship that citizens and political elites have with their legal institutions and each other; it is a cultural commitment to the law as a guide to behavior and "the project of law itself." 36 It is not enough to have a written legal code; there must also be a social commitment to abide by those laws, especially on the part of the political elite. ${ }^{37}$ Likewise, it is not enough that the judiciary is trained to be impartial. Individual judges must have an incentive to be impartial, which would require, for example, reducing the substantial political and financial rewards, such as promotions and bribes, for partial conduct. Lastly, it is not enough for the judicial process to run efficiently; ordinary citizens must have access to legal institutions and trust that outcomes will be fair. ${ }^{38}$ This trust is only possible if the government and political elite abide by the laws, especially when it is not in their individual interest to do so. Without any effort to address the cultural or political elements of the rule of law, reform efforts will stall.

Addressing this cultural or political element of the rule of law requires, at a minimum, fostering the will to reform on the part of the government and political elite. ${ }^{39}$ While empowering citizens is also a crucial element of fostering a rule of law culture, ${ }^{40}$ recalcitrant government officials and political elites can undermine such empowerment. The will to reform is more than simply a desire for reform; it requires political restraint to see such reform through.

\section{Challenges to Rule of Law Reform}

"[P]eople respond to incentives." 41 It takes great willpower to resist the rewards or punishments that incentives deliver. ${ }^{42}$ Promoting the will to reform on the part of political elites, therefore, requires the difficult task of changing the incentive structures such individuals face. Some recommendations, for example, have focused on curbing corruption by increasing salaries in the police and judicial sectors, while

36. STROMSETH ET AL., supra note 17 , at 75.

37. See Carothers, supra note 1 , at $7-8$ (explaining that the crucial step in rule of law reform lies with government officials refraining from placing themselves above the law).

38. See Carothers, supra note 5, at 20-21.

39. Id. at 22 .

40. STROMSETH ET AL., supra note 17, at 340-46.

41. WILliam EASTERLy, The EluSIVE QUEST FOR GROWTH: ECONOMISTS' AdVENTURES AND MisadventURES IN THE TROPICS 143 (2002) (arguing that incentives matter for economic growth).

42. See id. (equating changing incentives to "cutting away brambles" that block one's path). 
also increasing oversight by state reformers. ${ }^{43}$ While these recommendations are helpful, in practice the implementation of them has not solved the problem of corruption, in part because "it is extremely difficult to politely dislodge an ingrained culture of corruption at the highest levels." 44 This is true when the payoff of corruption to the individual is greater than the potential costs to that individual. ${ }^{45}$ If the payoff of political restraint for each individual is minimal, then that individual will have little incentive to exercise restraint, especially when no one else exercises such restraint. ${ }^{46}$ The will to reform, therefore, suffers from a collective action problem and is further hampered by the commitment problem, which is characterized by the resistance to change of those who currently benefit from the status quo. ${ }^{47}$ The collective action and commitment problems help to explain why the will to reform often does not emerge despite the likelihood that, in the aggregate, society will be better off if systemic corruption is curbed or government accountability is strengthened.

Formal and informal institutions determine the payoffs and, thus, the incentives that individuals face. ${ }^{48}$ Institutions, in this context, refer to rules and norms, including political and cultural norms, that act as constraints on human interaction. Both formal institutions, like written legal codes and judiciaries, and informal institutions, like the rewards and punishments of corruption, inform individual action by structuring incentives. ${ }^{49}$ "Institutions consist of formal rules, informal constraints (norms of behavior, conventions, and self imposed codes of conduct) and the enforcement characteristics of both." 50 True institutional change,

43. See, e.g., STROMSETH ET AL., supra note 17, at 213, 240-43.

44. Madalene O'Donnell, Corruption: A Rule of Law Agenda?, in Civil WAR AND THE RULE OF LAW, supra note 2, at 240.

45. See id. at 227 ("The single greatest challenge [reformers] face is intense opposition from political and economic elites who benefit tremendously from corruption.").

46. For a game-theoretic discussion of corruption and collective action, see Jakob Svensson, Foreign Aid and Rent-Seeking, 51 J. INT'L ECON. 437 (2000).

47. See Karla Hoff \& Joseph E. Stiglitz, Exiting a Lawless State, 118 ECON. J. 1474, 1474-77 (2008) (discussing one type of coordination and commitment problem inherent in moving to the rule of law from the lawless state). For the idea that collective action can only succeed when all participants perceive that they are better off under the new institution than under the status quo-that is, when the new institutions are selfreinforcing, see Barry R.Weingast, The Political Foundations of Democracy and the Rule of Law, 91 AMER. POL. SCI. REV. 245 (1997) (discussing the emergence and sustainability of political pacts).

48. Douglass C. North, Institutional Change: A Framework of Analysis 1 (unpublished manuscript), available at http://129.3.20.41/eps/eh/papers/9412/9412001.pdf.

49. See Douglass C. NORTH, Institutions, Institutional Change and ECONOMiC PERFORMANCE 3-6 (1990).

50. North, supra note 48 , at 2 . 
and not window-dressing change, is difficult. "But even more fundamentally, this institutional evolution takes time." 51 "[T] most important point about institutional change, which must be grasped if we are to begin to get a handle on the subject, is that institutional change is overwhelmingly incremental." 52 Changes, particularly to informal constraints, tend to occur gradually because reformers or other entrepreneurial individuals take advantage of opportunities to introduce changes at the margin..$^{53}$ One reason that true change tends to be at the margin is that the "larger the number of rule changes, ceterus [sic] paribus[,] the greater the number of losers and hence opposition." 54 Attempts to impose new formal institutions by fiat, such as by rewriting laws or holding formal elections for democratic government, impose new costs and benefits by changing the formal rules. Those who benefit from the old institutions face new costs and lose old benefits. Thus, those who would lose from the new system are likely to mount a strong opposition to such changes. ${ }^{55}$ Furthermore, even those who desire such reform may lack the commitment to it because of the personal rewards inherent in the old system. This argument helps to explain why there are so many nominal, rather than true, democracies and why countries with similar legal codes seem to function so differently. ${ }^{56}$ As Douglass North pointedly notes, "Formal rules may change over night, but informal constraints do not." 57

Due to the difficulty of changing the institutions and thus the incentive structures that political elites face, the will to reform is likely to occur gradually, if at all, as a result of individuals seeking

51. Deborah Brautigam, Governance, Economy, and Foreign Aid, STUD. COMP. INT'L DEV., Fall 1992, at 3, 7 .

52. NORTH, supra note 49 , at 89 .

53. Id.

54. North, supra note 48 , at 6 .

55. Kurt Weyland, Toward a New Theory of Institutional Change, 60 WORLD POL. 281, 288 (2008) ("Since, according to cognitive psychology, losses weigh far more heavily than gains, [powerful actors] undertake disproportional efforts to defend the status quo."); see also Hoff \& Stiglitz, supra note 47, at 1474 ("It is now well understood that [dysfunctional institutions] persist if there are politically powerful losers from reform and no way to promise them compensation credibly.").

56. See NORTH, supra note 49, at 101; Weingast, supra note 47 , at $254-55$ (providing an explanation for the differences between democracy in the United States and democracy in Latin America).

57. North, supra note 48 , at 8 . For the idea that formal rules are more susceptible to change than informal, cultural rules, see Gérard Roland, Understanding Institutional Change: Fast-Moving and Slow-Moving Institutions (unpublished manuscript), available at http://www.econ.berkeley.edu/ groland/pubs/gr3.pdf; STROMSETH ET AL., supra note 17, at 313 (noting that post-intervention societies may be more susceptible to institutional change due to the breakdown of the "old" institutions). 
opportunities to benefit from change. Until more positive change can be observed at a societal level, such changes are likely to occur at the margin, although they can subtly change the costs and benefits all others face. The change itself may appear to be sudden or drastic, such as when a dictator unexpectedly agrees to subject himself to a democratic election, but it can usually be explained by marginal changes that alter the incentives of the dictator, rendering a seemingly drastic change less risky than maintaining the status quo. ${ }^{58}$ If this analysis of informal institutional change is true, it explains why rule of law reform efforts have not been successful. Rule of law reform efforts have focused on one-size-fits-all solutions that are not sensitive to these entrepreneurial opportunities for real change and ignore the difficulty of changing informal institutions, cultural and political norms, and the incentives such institutions naturally create.

The will to reform is difficult to achieve in the best of circumstances, and very little is known about how to foster it. Working against reform efforts are elements that support the status quo and undermine the incentives for change. The next part explores how foreign aid can be one hindrance to reform.

\section{The Unintended Consequences of Foreign AID}

Foreign aid, whether in the form of Official Development Assistance (ODA) or conditional loans, presents a further challenge to rule of law reform because of its potential to perpetuate the negative incentive structures of government officials and political elites. Naturally, these consequences are unintended. The stated intent behind foreign aid efforts is to accelerate economic development and institutional reform, including rule of law reform. ${ }^{59}$ Foreign aid is based in part on the

58. See Avner Greif \& David D. Laitin, A Theory of Endogenous Institutional Change, 98 AM. POL. SCI. REV. 633, 639 (2004) ("[I]nstitutional change should have a quality of punctuated equilibria, where change is in actuality evolutionary but apparently abrupt, typically associated with a "crisis" revealing that the previous behavior is no longer an equilibrium.") (citing Steven Krasner, Approaches to the State: Alternative Conceptions and Historical Dynamics, 16 COMP. PoL. 223, 223-46 (1984)); Weyland, supra note 55, at 288 ("When a crisis looms, the aggregate benefits arising from a transformation can finally outweigh the disproportionate concern about losses held by the defenders of the existing system.").

59. See, e.g., Margareta Sollenberg, Aid Dependence and Armed Conflict: A ReExamination of the Evidence 2 (June 11, 2009) (unpublished manuscript), available at http:/www.prio.no/upload/cscw/wg3/GROW\%20net\%20Workshop/Sollenberg\%20Aid\&Conf lict\%20090604\%20(Oslo).pdf ("Although aid is meant to be solely beneficial for the recipient country, the aid community as well as the research community has long been aware of the possibility that aid may sometimes do harm, despite the donors' good intentions."). 
premise that it is difficult for developing countries to make needed reforms without the help of the developed world, particularly without their financial assistance. William Easterly has called this the "white man's burden," and it is the idea that even though much of the developed world has advanced without outside assistance, the developing world cannot do the same. ${ }^{60}$ With the white man's burden deeply ingrained in the minds of Western aid agencies, people have only recently begun to question this assumption and consider whether they are doing more harm than good.61

A survey of recent economic literature, primarily focused on the effects of foreign aid on economic development, reveals that foreign aid can undermine rule of law reform by reducing the costs of maintaining the status quo. In other words, foreign aid may hinder the emergence of a cultural or political commitment to the rule of law, particularly on the part of the political elite. If the cultural or political elements of the rule of law require political accountability to the rule of law and a commitment to maintaining a well-ordered society, then foreign aid can undermine that by thwarting the emergence of democracy and democratic accountability, ${ }^{62}$ decreasing the quality of governance, ${ }^{63}$ and

60. William Easterly, The White Man's BuRden: Why the West's EfForts to Aid THE REST HAVE DONE So MuCH ILl AND So LiTTLE GoOD 23-26 (2006). "The White Man's Burden emerged from the West's self-pleasing fantasy that 'we' were the chosen ones to save the Rest. The White Man offered himself the starring role in an ancien régime version of Harry Potter." Id. at 23.

61. The white man's burden is obviously a caricature to some extent, though it is an apt description of some of the imperialist elements found in the development literature. Of course, it may also be the case that the developed world simply believes they can accelerate the development of the developing world through development assistance. Still, even this premise is challenged by the failure of development in many countries that have been the primary focus of development assistance.

62. See, e.g., Stephen Knack, Does Foreign Aid Promote Democracy?, 48 INT'L STUD. Q. 251-66 (2004) (arguing there is no evidence to suggest foreign aid, in the aggregate, successfully promotes democracy).

63. E.g., Simeon Djankov et al., The Curse of Aid, 13 J. Econ. GrowTH 169 (2008); Brautigam, supra note 51, at 21 (arguing that "participatory dialogue between governments and their private sector, rather than between governments and donors" is more likely to yield effective property rights and accountability); Stephen Knack, Aid Dependence and the Quality of Governance: Cross-Country Empirical Tests, 68 S. ECON. J. 310,310 (2001) (discussing evidence that "higher aid levels erode the quality of governance, as measured by indices of bureaucratic quality, corruption, and the rule of law"); Raghuram Rajan \& Arvind Subramanian, Does Aid Affect Governance?, 97 AM. ECON. REV. 322, 322 (2007) (arguing that "countries that get more aid are likely to be the ones where [the quality of governance] is most adversely affected"); Svensson, supra note 46, at 437 (finding "no evidence that . . . donors systematically allocate aid to countries with less corruption"). But see José Tavares, Does Foreign Aid Corrupt?, 79 ECON. LETTERS 99 (2003) (producing a study that shows that aid decreases corruption). 
encouraging violent conflict or civil war. ${ }^{64}$ Each of these effects is a roadblock to the will to reform. The following sections discuss the impact of foreign aid on rule of law reform, focusing, in particular, on impediments like corruption, poor governance, and the lack of democratic accountability that foreign aid can create.

\section{A. Incentives for Rent Seeking and Corruption}

The role of governance in reform efforts cannot be overemphasized. "Good governance-in the form of institutions that establish a predictable, impartial, and consistently enforced set of rules . . - -is crucial for sustained and rapid growth in per capita incomes of poor countries."65 Not only is good governance, as defined above, good for economic growth, but it is also synonymous with certain aspects of the formal rule of law theory. ${ }^{66}$ While ODA, in theory, could promote good governance and the rule of law by increasing salaries and reducing corruption or by training the police and the judiciary, the unintended consequences of aid may overshadow any positive returns in these areas. ${ }^{67}$

Instead of promoting good governance, foreign aid can skew the incentives of governments and political elites. ${ }^{68}$ As one economic study reveals: "Analyses of cross-country data provide evidence that higher aid levels erode the quality of governance, as measured by indices of

64. See, e.g., Manuel Oechslin, Foreign Aid, Political Instability, and Economic Growth 1 (U. Zurich Inst. for Empirical Research Econ., Working Paper No. 310, 2006), available at https:/editorialexpress.com/cgi-bin/conference/download.cgi?db_name=res2007\&paper_id=489 (arguing that "more money in the hands of the regime fuels conflict over the distribution of funds"); Sollenberg, supra note 59, at 3 (finding that "aid dependence does increase the probability of armed conflict"). But see Paul Collier \& Anke Hoeffler, Aid, Policy and Peace: Reducing the Risks of Civil Conflict, 13 DEF. \& PEACE ECON. 435, 435 (2002) (finding "that aid and policy do not have direct effects upon conflict risk"); Joppe de Ree \& Eleonora Nillesen, Aiding Violence or Peace? The Impact of Foreign Aid on the Risk of Civil Conflict in SubSaharan Africa, 88 J. DEV. ECON. 301, 301 (2009) (finding that "increasing aid flows tends to decrease civil conflict duration"). The methodology of the Collier and Hoeffler article should be questioned, however, since it measured the effect of economic policy and foreign aid on the risk of conflict. It is unclear then what effect aid alone has on such risk. Still, because the relationship between aid and conflict is ambiguous, it is omitted from discussion here.

65 . Knack, supra note 63 , at 311.

66. See supra notes 12-13, 21-25 and accompanying text.

67. For a similar argument about foreign aid and democratization, see Knack, supra note 62 , at 251 .

68. For an argument linking foreign aid to the incentives of government officials, and in particular arguing that foreign aid, in the form of unconditional monetary transfers, decreases the incentives to institute "good policies," see Alberto Dalmazzo \& Guido de Blasio, Resources and Incentives to Reform, 50 IMF STAFF PAPERS 250 (2003). 
bureaucratic quality, corruption, and the rule of law."69 One reason for this is that foreign aid can be seen as a large prize to be won. ${ }^{70}$ Whoever controls the government also controls the money. Thus, a moral hazard problem results in that the people who end up in power tend not to be the same people who have sincere reform efforts in mind. ${ }^{71}$ As another study points out, "[h]igh levels of aid in countries where the political leadership does not have reform on the agenda are likely to reduce the incentive to cooperate in the sacrifices necessary for reform to occur."72 Rule of law reform, which seeks to build a society in which government officials and political elites abide by laws, runs counter to the power-asprize mentality because reform requires collective sacrifice on the part of political elites, who must eschew personal gain for the public good. ${ }^{73}$ The collective sacrifice requirement suffers from a quintessential prisoner's dilemma problem in that it is always in the individual's selfinterest to promote personal gain and thus not make sacrifices, regardless of whether anyone else does. ${ }^{74}$ The result is the equilibrium position in which few political elites or government officials are prepared to make the sacrifices necessary for reform. ${ }^{75}$

Foreign aid also represents a potential source of rents, which is a way for the political elite to maintain power. ${ }^{76}$ It is often easier to remain in power by patronage rather than by reform. "Political elites

69. Knack, supra note 63 , at 310 .

70. See Alberto Alesina \& Beatrice Weder, Do Corrupt Governments Receive Less Foreign Aid? 3 (Nat'l Bureau of Econ. Research, Working Paper No. 7108, 1999) (citing Philip Lane \& Aaron Tornell, The Voracity Effect, 89 AM. ECON. REV. 22 (1999)).

71. For example, Stephen Knack notes that "[a]id may also encourage coup attempts and political instability, by making control of the government and aid receipts a more valuable prize, reducing the prospects for democratic governance. It is widely acknowledged that violent competition for control over large-scale food aid contributed to the breakdown of government in Somalia." Knack, supra note 62, at 253 (finding overall that aid has no positive or negative effect on democracy in recipient governments).

72. Deborah A. Brautigam \& Stephen Knack, Foreign Aid, Institutions, and Governance in Sub-Saharan Africa, 52 Econ. DeV. \& CUltuRAL ChANGE 255, 263 (2004).

73. Id. at 256 .

74. For an overview of the prisoner's dilemma problem, see Steven Kuhn, Prisoner's Dilemma, in ThE STANFORD ENCYClOPEDIA OF PHILOSOPHY (Edward N. Zalta ed., 2009), available at http://plato.stanford.edu/archives/spr2009/entries/prisoner-dilemma/.

75. One study by George Economides, Sarantis Kalyvitis, and Apostolis Philippopoulos finds that "the deleterious effect of aid upon incentives . . . is significant only in recipient countries with relatively large public sectors. This confirms the popular belief that rent seeking and corruption take place mainly through government activities ...." Does Foreign Aid Distort Incentives and Hurt Growth? Theory and Evidence from 75 AidRecipient Countries, 134 PUB. CHOICE 463, 464 (2008). In those countries with large public sectors, "foreign aid makes . . . a cooperative solution [i.e., one without rent seeking] more difficult to sustain." Id. at 484.

76. Knack, supra note 63 , at 313 . 
have little incentive to change a situation in which large amounts of aid provide exceptional resources for patronage and many fringe benefits (vehicles, study tours, salary increments, etc.) that would not otherwise be available to officials in low-income countries."77 Reform is often painful and unpopular with those who benefit from the status quo. The incentive for reform is lessened when power can be retained by force or patronage without having to make unpopular reforms. Even for reformminded elites, the incentive to forestall reform is great; "it is in the interests of all actors today to continue the benefits they get from . . . receiving aid, even though this aid will create problems for future governments."78 Given that most government officials and political elites have short time horizons, ${ }^{79}$ it is easier to leave real reform for the next government and to take advantage of the present, personal gains from aid as they come. ${ }^{80}$

Lastly, foreign aid increases the opportunity for corruption, meaning "the illegal use of public office for private gain." 81 Corruption may be blatant, like the diversion of foreign aid to private Swiss bank accounts, ${ }^{82}$ but corruption also occurs when aid money is used to provide government positions for cronies or political allies or fund projects supported by the political elites. ${ }^{83}$ Despite arguments that aid can reduce corruption by raising the salaries of government officials, an empirical study reveals that countries that receive more aid tend to have higher corruption. ${ }^{84}$ While it may be difficult to make a conclusive causal argument that aid causes corruption, a potential endogeneity problem is minimized because there is little risk that increased corruption causes increased aid flows. ${ }^{85}$

Again, there is a collective action problem involved with reducing corruption. Considering the incentives of political elites to eschew corruption through a prisoner's dilemma choice set, each individual maximizes his self-interest by engaging in corrupt behavior in both

77. Brautigam \& Knack, supra note 72, at 263.

78. Id. at 265 .

79. Knack, supra note 63 , at 311 . For an argument that foreign aid may decrease the time horizon of governments by increasing potential for conflict over the distribution of funds, see Oechslin, supra note 64.

80. For the proposition that aid reduces the cost of "doing nothing-that is, avoiding reform," see Dani Rodrik, Understanding Economic Policy Reform, 34 J. ECON. LIT. 9, 3031 (1996).

81. Brautigam, supra note 51 , at 13 (citing RoBIN THEOBALD, CoRRuPtion, DEVELOPMENT AND UNDERDEVELOPMENT (1990)).

82. See Todd Moss \& Arvind Subramanian, After the Big Push? Fiscal and Institutional Implications of Large Aid Increases 7 (Ctr. for Global Dev., Working Paper No. 71, 2005).

83. Knack, supra note 63, at 313.

84. Alesina \& Weder, supra note 70 , at 20 .

85. Id. at 6-7. 
scenarios: (1) if everyone else resists corrupt behavior, or (2) if everyone else engages in corrupt behavior. The decision set is identical for each actor. Thus, the equilibrium behavior is corruption, rather than restraint. ${ }^{86}$

Given the incentives governments face, the ineffectiveness of aid to improve governance should not be surprising. One of the problems with foreign aid or rule of law aid is that once the laws are rewritten and the judiciary is trained, reformers in aid agencies do not promote sustainable reform efforts. ${ }^{87}$ If the aid continues despite the lack of real reform, recipient governments will do just enough to guarantee a continued flow of revenue. Real reform, however, can only go so far with a carrot-and-stick enforcement policy. Real reform also requires a commitment to reform even when no one is watching. It has been noted that " $t]$ he single greatest challenge [reformers] face is intense opposition from political and economic elites who benefit tremendously from corruption." 88 Rule of law reformers still do not know how to build the normative commitment to rule of law reform. Perhaps, there is no easy way to do so. In the meantime, the commitment is undermined by the subsidization of the status quo provided by foreign aid.

86. In the traditional prisoner's dilemma scenario, there are two suspects who each face the choice of testifying against the other or remaining silent. If both suspects remain silent, there is not enough evidence to charge them with the serious offense and they will each get six months in prison. However, if one testifies and the other remains silent, the one that testifies will go free, while the other will be sentenced to ten years in prison. If both suspects testify against the other, they will both get five years. Because each suspect risks going to prison for ten years if he stays silent, each suspect will testify against the other. As a result, each will get a five-year sentence. Both would be better off if they can agree to keep silent, but they cannot coordinate their actions.

The collective action problem for corruption is similar in that without a disincentive to engage in corruption, each political elite would maximize his self-interest by defecting, and taking bribes, than from agreeing to eschew corruption, even if all of the other political elites agree to eschew corruption. Because each political elite gains from defecting on any agreement, the equilibrium is corruption.

For an example of this type of game-theoretic response to foreign aid, see Svensson, supra note 46. Svensson concludes that this result is more prominent in societies that are politically or culturally divided. Id. at 455 .

87. The stories of aid projects rendered useless without continued monitoring on the part of the aid agencies are countless. See, e.g., MiCHAEL MAREN, THE ROAD TO HELL: THE RAVAGING EFFECTS OF FOREIGN AID AND INTERNATIONAL CHARITY (1997). Aid agencies need to monitor these projects because none of the agencies' efforts reach the human element or the will to reform. With the will to reform, no oversight would be required.

88. O'Donnell, supra note 44 , at 227. 


\section{B. Thwarting the Emergence of Democratic Governance}

Perhaps the most notable and widely discussed consequence of foreign aid stems from its effect on democracy and democratic accountability. Rentier state theory, originally modeled to explain why oil-rich Middle Eastern states tend to be authoritarian, argues that countries that rely predominantly on external rents, like oil profits or foreign aid, are less accountable to civil society than are governments that must rely on tax revenue. ${ }^{89}$ The argument against foreign aid is that by producing external rents, the state can function without the need to tax its citizens. ${ }^{90}$ As the flip side of the Revolutionary War slogan, "no taxation without representation," the idea of "no representation without taxation" might be equally compelling. While most recipient governments do tax their citizens to some extent, tax collection efforts are often grossly inefficient. Foreign aid reduces the pressure to introduce tax reform. Indeed, "[s]eventy-one percent of the African countries receiving more than $10 \%$ of GDP in aid in 1995 were also in the group of countries judged in an IMF study to have lower than expected tax effort." 91

Historians and political scientists have argued that the demand for representation in government arose in response to the sovereign's attempts to raise taxes. ${ }^{92}$ Essentially, the sovereign's need for revenue forced it into the bargaining process with citizens. ${ }^{93}$ Without the pressure of raising revenue, the bargaining position of citizens is diminished.

The "taxation produces representation" claim is most commonly invoked today by Middle East specialists who reason that the ability of the region's autocrats to finance themselves with non-tax revenues-primarily through oil revenues-has enabled them to avoid pressures to democratize. . . [T] [The discovery of oil allowed the governments of Kuwait and Qatar to stop taxing their merchant classes; relieved of taxes, the

89. Michael Lewin Ross, Does Oil Hinder Democracy? 53 WORLD POL. 325, 329-32 (2001).

90. See Djankov et al., supra note 63 , at 3 .

91. Brautigam \& Knack, supra note 72 , at 264.

92. Ross, supra note 89 , at $332-33$. For an argument that the sources of state revenue may have a major impact on governance in developing countries, see Mick Moore, Revenues, State Formation, and the Quality of Governance in Developing Countries, 25 INT'L POL. SCI. REV. 297 (2004).

93. See Michael L. Ross, Does Taxation Lead to Representation?, 34 BRIT. J. Pol. ScI. 229, 230-32 (2004). 
merchants relinquished their historically-established right to participate in policy making. Similarly, . . . a drop in foreign aid and remittances in the 1980s forced the Jordanian government to depend more heavily on taxes: from 1987 to 1992 , the ratio of taxes to gross domestic product (GDP) rose from 0.13 to 0.24 . Rising taxes and falling subsidies led to riots in April 1989, a revision in the election laws, and following a November 1989 vote, a more open, representative and influential parliament. ${ }^{94}$

The idea is that, like citizens of oil-rich countries, citizens of countries in which foreign aid makes up a significant portion of revenue will also have less bargaining power vis-à-vis the state. Less bargaining power translates into fewer mechanisms to hold the government accountable and less democratic representation..$^{95}$

The "taxation produces representation" theory holds that, all other things being equal, higher taxes will tend to produce greater accountability and democratic representation. This is because higher taxes create an incentive for citizens to put pressure on the government and demand greater accountability and respect for the rule of law. The government's need for revenue gives citizens a position at the bargaining table. However, higher taxes coupled with a greater provision and quality of government services might not produce these same results. The reason is that "[b]oth the size of the tax burden, and the quality and quantity of government spending matter; citizens ultimately care about the 'price' they pay for the government services they receive." 96 If citizens feel the benefits of government services outweigh the costs, their incentive to demand change decreases. Thus, the resulting theory is that higher taxes, without a complementary improvement in government services, will result in greater government accountability and democratic representation as a result of increased pressure by citizens on the state. "People may dislike taxes," Michael Ross notes, "and indeed they loathe paying more while receiving less from their governments. Ironically, [though,] this loathing may be a good thing: when citizens are faced with an undemocratic government that is charging unreasonably high prices for its services, they tend to demand democratic reforms." 97

94. Id. at 232-33.

95. See generally id. 233-34.

96. Id. at 234 .

97. Id. at 248 . 
Foreign aid, like oil, is a measure that helps authoritarian governments lower the price of government services, thereby increasing services for the same price or decreasing the price for the same services. ${ }^{98}$ Either one of these results has antidemocratic effects since it decreases citizens' incentives to demand changes and decreases citizens' bargaining position vis-à-vis the government.

Unlike oil or other natural resources, foreign aid does not fall from the heavens nor spew from the earth, like manna. Because foreign aid has its source in human agents, it is necessary to consider those agents' role. When a government taxes its citizens, it is in some way accountable to them to produce the expected results. Since foreign aid bypasses or decreases the government's need to tax citizens, governments become less accountable to their citizens. Instead, government officials become accountable to foreign donors:

When aid transfers reach ten percent or more of total GNP (as they did for at least 24 countries in 1989) and exceed total current revenue from other sources, those with the loudest single voice . . . are international lending agencies. ${ }^{99}$

So, the question becomes: do international lending agents keep governments accountable? In particular, do international lending agents keep governments accountable to rule of law reform?

The simple answer to this question is no, but the reasons for this are more complex than the answer. Understanding why lending agents fail to keep governments accountable to the rule of law requires understanding the multidimensional, principal-agent relationship lurking behind this interaction. In the idealized citizen-state relationship, the citizens are the principals. They are the owners of the valuable resources and revenues that are transferred to the agent, namely the state, through taxation. In the case of foreign aid, instead of the citizens, the principals are the international lenders, while the agent is the recipient state. On this one dimension, then, the recipient state is accountable to the aid agencies. The story is more complicated, however, because the aid agencies themselves are agents for yet other principals, namely the citizens in the donor countries whose tax dollars fund the agencies. ${ }^{100}$ Moreover, the aid agencies rely on the presumption that the recipient governments are agents of their citizens, as

98. Id. at 247; see also Djankov et al., supra note 63 , at 3.

99. Brautigam, supra note 51 , at 11 (citing WORLD BANK, WORLD DEVELOPMENT REPORT 1991, at 242 (1991)).

100. EASTERLY, supra note 60, at 169. 
principals. Bertin Martens refers to this multidimensional principalagent relationship as a "broken feedback loop" because there are no smooth channels in this relationship for proper feedback. ${ }^{101}$

The lack of feedback between the recipient government and its citizens has already been discussed, but what about the feedback between the recipient government and aid agencies? If citizens cannot induce the government or political elites to work toward rule of law reforms, can aid agencies? The problem here is that aid agencies have an incentive to continue producing output (i.e., increase grants and loans), regardless of whether the recipient governments reform. ${ }^{102}$ The reason is that the principals to the aid agency-donor relationship are the citizens in donor countries, and these citizens have almost no ability to monitor the effect of aid on rule of law reform, particularly on the will to reform. ${ }^{103}$ As a result, the success of the aid agencies is measured by the volume of input-money given, in other words-as opposed to output or real reform. ${ }^{104}$ To highlight this fact, instead of complaining about the trillions of dollars of aid that has been given without any remarkable change in the rule of law or economic well-being in the recipient countries, the rhetoric in donor countries is that more aid is needed. Several influential celebrities, most notably Bono, ${ }^{105}$ as well as prominent academics, such as Columbia University professor Jeffrey Sachs, ${ }^{106}$ believe that doubling aid to poor countries will somehow produce a different result than the first few trillion. ${ }^{107}$ Citizens in the donor countries "love the Big Plans, the promises of easy solutions, the utopian dreams, [and] the side benefits for rich-country political or

101. See generally BERTIN MARTENS ET AL., ThE INSTITUTIONAL ECONOMics OF FOREIGN AID, at viii-9 (2002). See also William Easterly, Was Development Assistance a Mistake? 97 AM. ECON. REV. 328, 330 (2007) ("Unlike the provision of domestic public goods in democracies, the recipient of aid-financed public services has no ability to register dissatisfaction through voting. With little or no feedback from the poor, there is little information as to which aid programs are working.").

102. See generally Jakob Svensson, Why Conditional Aid Does Not Work and What Can Be Done About It?, 70 J. DEv. ECoN. 381, 398 (2003) ("['T]here is a strong bias towards 'always' disbursing aid to the ex ante designated recipient, irrespective of that recipient's performance....").

103. EASTERLY, supra note 60 , at 170-71.

104. Id. at 181-83.

105. Bono has been an influential part of the Live 8 concert series. The message of the Live 8 movement is to "make poverty history." As part of the program, 30 million people provided their names to a list presented to then-Prime Minister Tony Blair in order to influence Great Britain's foreign aid efforts in Africa. See http://www.live8live.com.

106. See JeFFrey SACHS, The END Of POVERTY: ECONOMIC PossibILITIES FOR OUR TIME

(2005) (Bono wrote the foreword for this book and has traveled extensively with Professor Sachs throughout Africa).

107. EASTERLY, supra note 60 , at 170. 
economic interests, all of which hands the aid agency impossible tasks." 108 More importantly, they are more than willing to take on the white man's burden without demanding observable results. Thus, the aid agencies lack the incentives to demand those results from recipient countries, especially since, as this Note has argued, real results are difficult to achieve.

The other problem with aid agencies' incentives is that their continued existence depends on the premise that foreign aid can produce reform. If foreign aid is anathema to reform, the aid agency has no purpose and will not continue to be funded. As a result, agencies have an incentive not to give up on the hope that aid can bring reform and growth. This hope has spurred new trends and theories on how to make aid work for developing countries, including directing aid toward countries with better institutions and using economic sanctions to threaten governments and political elites into reform. While these efforts almost certainly result in some improvements, the unintended negative effects of aid overshadow those improvements, leaving many countries worse off after fifty years of development aid than they were before. ${ }^{109}$ This unfortunate conclusion is especially prominent on the African continent.

\section{THE EXPERIMENT IN AFRICA}

Over the past 42 years, over 500 billion dollars in foreign aid has been funneled to Africa. ${ }^{110}$ However, little progress has been made in many African countries, particularly in economic development and rule of law reform. This is especially true in the African countries that can be labeled "aid dependent" (a label that means ten percent or more of a country's GDP comes from external revenue sources).111 Foreign aid alone, however, does not explain the relative absence of the rule of law in many aid-dependent African countries, since many of these countries came into existence with relatively poor legal and political institutions. Instead, the argument is that foreign aid perpetuates the continued existence of these poor institutions by removing the incentive to engage in real reform. The following subsection presents a theory about why many African countries have weak rule of law cultures. If this theory is accurate, it highlights the reason why foreign aid may undermine the development of rule of law cultures in these countries. This theory is

108. Id. at 169.

109. Thomas W. Dichter, Despite Good Intentions: Why Development Assistance TO THE THIRD WORLD HAS FAILED 2 (2003).

110. Easterly, supra note 101, at 329.

111. See Brautigam \& Knack, supra note 72 , at 257. 
also bolstered by the empirical data on sub-Saharan Africa surveyed in the previous part, 112 which is where most of the aid-dependent African countries are found.

\section{A. African Institutions: An Explanation for the Weak Rule of Law Culture in Much of Sub-Saharan Africa}

In his book, Indigenous African Institutions, Ghanaian economist George Ayittey explores the nature of precolonial African institutions. ${ }^{113}$ Ayittey found that precolonial or indigenous African societies did not necessarily have weak rule of law cultures. ${ }^{114}$ In fact, many such societies evidenced indigenous dispute resolution institutions, including informal courts complete with rights of appeal. ${ }^{115}$ In much of precolonial Africa, however, indigenous courts stressed "reconciliation and the promotion of social harmony," as opposed to strict fidelity to abstract legal codes. ${ }^{116}$ Indigenous African courts also encouraged public participation, thereby increasing social harmony and compliance with the outcome of the case.117 While fidelity to abstract legal codes may have been lacking, indigenous African legal institutions were most often based on customary law that represented long-established, socially accepted norms. ${ }^{118}$ The political or cultural elements of the rule of law can be evidenced in these indigenous institutions. For example, in Segment v. Makgala Kopo, "a man who had forcibly attacked another's household goods to secure payment of a debt was fined two head of cattle, because, said the chief, "the law (native law) is that a person should not seize from another but must bring him to the chief."119 This case, as one of many Ayittey cited, illustrates his conclusion that indigenous African legal institutions required disputes to be settled through the legal system, based on well established and socially accepted rules, which is further evidence of the cultural commitment to the rule of law.

If Ayittey accurately describes the state of many indigenous African institutions, then it is relevant to ask: what went wrong? Ayittey's theory, which garners further support in the literature, ${ }^{120}$ places the

112. See supra Part II.

113. See generally GEORGE B.N. AYTTTEY, INDIGENOUS AFRICAN INSTITUTIONS (1991).

114. Id. at 39-149.

115. Id. at $40-41$.

116. Id. at 67 .

117. Id. at $67-68$.

118. Id. at $60-66$.

119. Id. at 60 .

120. See, e.g., Pierre Englebert, Pre-Colonial Institutions, Post-Colonial States, and Economic Development in Tropical Africa, 53 PoL. RES. Q. 7 (2000) ("IV]ariations in the 
blame on the shoulders of the colonial powers and the postcolonial independent governments that succeeded these indigenous institutions. ${ }^{121}$ The theory is that poor institutions are the result of a conflict or disconnect between the colonial and postcolonial transplanted institutions and the indigenous institutions. ${ }^{122}$ When the postcolonial independent governments strongly conflicted with the precolonial indigenous institutions, the theory states that governments resorted to "neo-patrimonial strategies of power with their attendant propensity for corruption, clientelism, nepotism, or regionalism"123 to remain in power. Neo-patrimonial institutions are characterized by the presence of a central figure-a "big man," a President, or a father figure-who uses state resources to secure the loyalty of citizen "clients" and who sees the office of President as a means of personal aggrandizement.124 "Neopatrimonial policies are ... the equilibrium outcome of illegitimate postcolonial statehood, a condition which entails a dichotomization of power and state structures." 125

This theory is buttressed by its ability to explain the differences in the existence of neo-patrimonialism among sub-Saharan African countries. In countries such as Botswana, in which the postcolonial government was coextensive with the precolonial institutional structure, neo-patrimonial activities are minimized. ${ }^{126}$ By contrast, in the Democratic Republic of Congo (formerly Zaire), where the postcolonial state replaced separate state systems and nonstate societies, and where the borders of the postcolonial state divided precolonial political cultures, ${ }^{127}$ political conflict and neo-patrimonial,

extent to which post-colonial state institutions clash with pre-existing ones largely account for what differentiates state capacity and economic growth across the region. The greater the incongruence between pre- and post-colonial institutions, the greater the relative power payoffs to domestic elites of adopting neo-patrimonial policies over developmental ones.").

121. AYITTEY, supra note 113 , at $\mathrm{xv}$-xxiii.

122. See Englebert, supra note 120.

123. Id. at 12 .

124. See, e.g., id. at 9; Nicolas van de Walle, Presidentialism and Clientelism in Africa's Emerging Party Systems, 41 J. MOD. AFR. STUD. 297, 309-13 (2003) (using the terms "presidentialism" and "clientelism" in essentially the same way as "neo-patrimonialism").

125. Englebert, supra note 120, at 12.

126. Id. at 13-14. Englebert finds that the precolonial government in Botswana was firmly established prior to colonization. Id. In fact, Botswana's precolonial authorities requested the establishment of a British protectorate, fearing encroachment of the Boer settlers from South Africa. Id. at 13. Because of this, there was little or no chasm between the pre- and postcolonial state. Id. at 14 .

127. Id. at 13. 
"strong man" rule is at its most salient. ${ }^{128}$

If the disjunct between the modern state, with its formal institutions, and the indigenous institutions produces such a neopatrimonial power structure, it is hardly surprising that the rule of law is weak in countries that exhibit such behavior. By its definition, neopatrimonialism presumes the President or big man is above the law. Neo-patrimonial regimes "are highly presidential, in the sense that power is centralized around a single individual, with ultimate control over most clientelist networks." 129 These clientelist networks include "patronage, various forms of rent-seeking, and prebendalism."130 This type of power structure is anathema to the rule of law. It is also resistant to reform because real reform requires the participation of government officials and the political elite. However, when political power depends on the patronage system-employing corruption and rent seeking behavior and lacking accountability to the citizenry and the rule of law-no rule of law reform is likely to occur.

Part II of this Note emphasized how foreign aid organizations provide perverse incentives to resist reform by subsidizing the status quo. It illustrated how foreign aid can have an adverse effect on the quality of governance, as measured by corruption and the rule of law, and how it can thwart the emergence of democratic accountability. If legal, political, and cultural institutions of many sub-Saharan African countries are already plagued by poor governance and a lack of democratic accountability, adding foreign aid to the mix has the potential to entrench these policies even more deeply, making reform less, rather than more, likely. ${ }^{131}$

This short history of rule of law institutions in Africa reveals a partial explanation for the continent's poor rule of law record: the displacement of rule of law institutions and norms by colonial and postcolonial powers. Foreign aid, however, provides another part of this story; foreign aid has the potential to exacerbate the situation by subsidizing the status quo and decreasing the incentives toward government reform and democratic accountability. The following section provides a survey of empirical data from sub-Saharan Africa that shows this potential has largely been realized.

128. For a detailed examination of "strong man" politics in many postcolonial African nations, see generally MARTIN MEREDITH, THE FATE of AFRICA: A HistoRY OF FifTY YEARS OF INDEPENDENCE (2005).

129. Nicolas van de Walle, African Economies and the Politics of Permanent CRISIS, 1979-1999, at 52 (2001).

130. Id.

131. Id. at 58-60. 


\section{B. The Effects of Foreign Aid on the Weak Institutions in Sub-Saharan Africa}

Many countries in sub-Saharan Africa can be classified as aiddependent. ${ }^{132}$ If the theory presented in the previous section is accurate, empirical data should reveal that foreign aid has decreased, or at least failed to increase, the quality of governance in these countries. It should also reveal that foreign aid has decreased, or at least failed to improve, democratic accountability in these countries. Both the quality of governance and democratic accountability are proxies for the rule of law and, in particular, the cultural or political commitment to the rule of law. Poor institutions, including those marred by poor governance and a lack of democratic accountability, are not only proxies for the lack of the rule of law, but they also make the will to reform less likely.

132. Between 2000 and 2008, twenty-three sub-Saharan African countries received an average of ODA as a percentage of GDP greater than or equal to ten percent. See $A D B$ Socio-Economic Database, AFR. DEV. BANK, http://afdbdp.prognoz.com/DataAnalysis.aspx (last visited Feb. 6, 2011) (click "Data Analysis" on the left-hand column; under the title "Fixed" on the left-hand column, click the drop-down box labeled "Indicators"; select the "Financial Flows" arrow; choose "Net Total ODA/OA (In \% of GDP)").

\begin{tabular}{|l|l|}
\hline Country & Average ODA (as $\%$ of GDP) \\
\hline Burkina Faso & 13.42 \\
\hline Burundi & 37.92 \\
\hline Cape Verde & 14.41 \\
\hline Congo, Dem. Rep. & 25.33 \\
\hline Djibouti & 12.09 \\
\hline Eritrea & 24.21 \\
\hline Ethiopia & 14.70 \\
\hline Gambia & 13.79 \\
\hline Ghana & 11.06 \\
\hline Guinea-Bissau & 32.22 \\
\hline Liberia & 58.75 \\
\hline Rwanda & 20.85 \\
\hline Madagascar & 12.93 \\
\hline Malawi & 20.97 \\
\hline Mali & 13.03 \\
\hline Mauritania & 16.13 \\
\hline Mozambique & 25.35 \\
\hline Niger & 14.60 \\
\hline Sao Tome \& Principe & 32.46 \\
\hline Sierra Leone & 31.54 \\
\hline Tanzania & 12.67 \\
\hline Uganda & 12.75 \\
\hline Zambia & 16.11 \\
\hline
\end{tabular}


A look at some of the empirical studies that focus on sub-Saharan Africa shows that foreign aid does not have a positive effect on the quality of governance, corruption, and democratic accountability in Africa. A study conducted by Deborah Brautigam and Stephen Knack tested the effect of aid dependence on the quality of governance in subSaharan Africa and measured it by subjective indices from the International Country Risk Guide, which is a commercial service providing information on political risks to overseas investors. They also tested the effect of aid on the tax collection effort of sub-Saharan African countries. Their results "show that in Africa, higher aid levels are associated with larger declines in the quality of governance and in tax revenues as a share of GDP." 133 Moreover, when they corrected for the potential endogeneity of aid, recognizing that "causality can go in either direction, as donors may respond (either favorably or unfavorably) to an observed deterioration in governance," 134 they found "an even stronger relationship between aid levels and declines in the quality of governance and in the tax share of GDP."135 The results of Brautigam and Knack's study remains significant when they control "for economic decline and political violence, [which are] two factors that might also affect governance and tax collections," 136 signaling the role of aid on the poor governance in many sub-Saharan African countries. Finally, there is no conclusive evidence that aid was less damaging to governance in recipient nations after the development industry began implementing programs that targeted corruption, strengthened tax administration, and supported democratization, than before the advent of the reforms. ${ }^{137}$

The studies surrounding the effects of foreign aid on democratic accountability are more opaque. Democratic accountability is itself difficult to measure. The fact that a government holds regular elections does not necessarily speak to the fairness of those elections or the government's willingness to conform to the results of the election if the incumbent loses. ${ }^{138}$ Moreover, regular elections, even if fair and subject to real opposition, do not reveal whether citizens have any power to hold governments accountable to the rule of law or its reform. While recent studies have shown a slight positive effect of aid on democracy, these results must be qualified. In one study, Arthur Goldsmith found "small

133. Brautigam \& Knack, supra note 72 , at 266.

134. Id.

135. $I d$.

136. Id.

137. Id. at 275 .

138. See generally ADAM PRZEWORSKI ET AL., DEMOCRACY AND DEVELOPMENT: POLITICAL INSTTTUTIONS AND WELL-BEING IN THE WORLD, 1950-1990, at 15-18 (2000). 
positive relationships between aid and indicators of democracy." 139 However, the study measures democracy by the Freedom House rating system of "free," "partly free," and "not free," "based on an index of how much liberty citizens have to organize themselves for common purposes, to persuade others of their opinions, and to compete for political influence." 140 Unfortunately, seven of the twenty-three aid-dependent countries, as identified by the African Development Bank, fall under the category "not free," while only four fall under the category "free."141 Yet even this measurement cannot capture the idea of whether the governments in any of these countries are accountable to their citizens or whether citizens have a real effect on government policies, as true democratic accountability requires. ${ }^{142}$ Moreover, other research on the democratic situation in sub-Saharan Africa paints a less-than-rosy picture of the nature of democratic elections. ${ }^{143}$ As Said Adejumobi notes:

In most African countries, recent developments suggest that elections are only an expedient political exercise for ruling regimes, partly because of their economic implications in terms of external aid flows and economic assistance, and partly because of their public relations advantage in propping up the political profile of the regime in the international arena. ${ }^{144}$

139. Arthur A. Goldsmith, Foreign Aid and Statehood in Africa, 55 INT'L ORG. 123, 144 (2001).

140. Id. at $128-30$.

141. See id. at 129-31. Burundi, The Democratic Republic of Congo, Djibouti, Gambia, Mauritania, Niger, and Rwanda are classified as "not free," whereas Cape Verde, Malawi, Mali, and Sao Tome \& Principe are classified as "free." The remaining countries are classified as "partly free." Goldsmith's data comes from the late 1990s. In the 2010 report, Malawi has been downgraded from "free" to "partly free." However, Burundi, Djibouti, Gambia, and Niger have been upgraded to "partly free." The remaining countries are classified as "partly free." FREEDOM HOUSE, FREEDOM IN THE WORLD (2010), available at http://www.freedomhouse.org/uploads/fiw 10/CombinedAverageRatings(IndependentCount ries)FIW2010.pdf.

142. The chart Goldsmith provides shows that even those governments rated "free" by Freedom House exhibited periods of "internal wars and state failures," "deaths from political violence," "refugees," and "coup events." Goldsmith, supra note 139, at 129-30.

143. See, e.g., Said Adejumobi, Elections in Africa: A Fading Shadow of Democracy?, 21 INT'L POL. SCI. REV. 59, 59 (2000) (arguing that the structure and process of elections in most African states "remain largely perverted").

144. Id. at 66. 
Stories of rigging elections, stifling opposition parties, and terrorizing citizenry abound in many of these countries. ${ }^{145}$ More telling, perhaps, is that there are no unqualified studies purporting to hold that foreign aid has had a direct positive effect on democratic accountability, as opposed to an effect on the existence of multiparty elections.

\section{CONCLUSION}

It is the presumption of the development industry that foreign aid can promote rule of law reform by providing the resources necessary to rewrite formal legal codes, train judiciaries and police forces, and introduce technology that may help legal institutions function more efficiently. This Note has highlighted both theoretical and empirical evidence as to why foreign aid has failed to lead to rule of law reform in many countries. The fundamental problem the development industry overlooks is the lack of incentives for developing countries' government officials and political elites to aid in the reformation of the rule of law. An important aspect that is also often overlooked is that true rule of law reform will not be sustainable without a social commitment to abide by the rule of law, especially on the part of government officials and the political elite. The development industry has thus far failed to develop the underlying institutions that create this social commitment.

Contrary to what the development industry intends to achieve by offering foreign aid, aid often has the unintended consequence of subsidizing present institutions, thereby postponing the need to make necessary reforms. An influx of aid money provides few incentives for political elites to commit themselves to the sacrifices required for real reform and democratic accountability, and it enables the elite to remain in power without such reform.

While this Note has presented a pessimistic view of foreign aid and its ability to accelerate rule of law reform in developing countries, its arguments are limited to the way in which foreign aid is currently delivered. The challenges, however, are great. Previous attempts to attach conditions for reform on development assistance have failed to engender true reform, precisely because the parties on both sidesgovernment officials, political elites, and the aid agents themselvesface incentives contrary to the end goal. The aid agents face incentives to continue giving aid even when real reform is not forthcoming, and the political elites in the recipient countries are incentivized to stifle change while continuing to receive aid revenue. If aid is to provide the means

145. See generally MEREDITH, supra note 128 (providing numerous examples of misrule in African countries). 
for true reform, the development industry must discover some way to overcome these adverse incentives. 